\title{
Deskripsi Tingkat Pemahaman Konsep Perpangkatan Siswa Kelas XI Menggunakan Certainty of Response Index (CRI)
}

\author{
Hamzah Upu ${ }^{1, \text { a) }}$, Ahmad Talib ${ }^{1, \text { b) }}$, dan St. Hartina Tahir ${ }^{1, c)}$ \\ ${ }^{1}$ Jurusan Matematika FMIPA Universitas Negeri Makassar, 90224

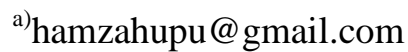 \\ b)ahmad.talib@unm.ac.id \\ c)hartinatina9@gmail.com
}

\begin{abstract}
Abstrak. Penelitian ini bertujuan untuk mengetahui dekripsi pemahaman konsep siswa yaitu paham konsep dengan baik, paham konsep tetapi kurang yakin, miskonsepsi, dan tidak tahu konsep pada materi perpangkatan menggunakan Certainty of Response Index (CRI). Jenis penelitian ini adalah penelitian kualitatif dengan pendekatan deskriptif. Subjek penelitian sebanyak 11 subjek yang mewakili setiap tingkat pemahaman konsep dari siswa kelas XI SMA. Instrumen penelitian terdiri dari tes objektif dan pedoman wawancara. Tingkat pemahaman konsep dikategorikan menggunakan kategori CRI. Hasil penelitian menunjukkan bahwa: (1) Siswa paham konsep dengan baik disebabkan oleh tingginya motivasi belajar dan rasa suka siswa pada pelajaran matematika. (2) Siswa memahami konsep tetapi kurang yakin disebabkan oleh rendahnya rasa percaya diri, rasa takut salah yang tinggi, kurang menguasai konsep matematika, dan tergesa-gesa dalam menjawab soal. (3) Siswa mengalami miskonsepsi disebabkan oleh kurangnya pemahaman bahkan salah paham konsep. (4) Siswa tidak memahami atau tidak tahu konsep disebabkan oleh siswa tidak memiliki pengetahuan dalam mengerjakan soal perpangkatan, kurangnya kemampuan dan wawasan siswa dalam mengerjakan soal, kurang menguasai konsep, tidak memahami soal, dan kurangnya kemampuan siswa dalam mentransformasikan soal.
\end{abstract}

Kata Kunci: Pemahaman, Konsep, Perpangkatan, Miskonsepsi, Certainty of Response Index (CRI)

\begin{abstract}
This study aims to determine the students understanding concept in terms of understanding the concept as well, understanding the concept but not sure, misconception, and not knowing the concept of exponent using Certainty of Response Index (CRI). The type of this study is qualitative study with descriptive approach. The subject of this study is 11 subjects who represent each level of conceptual understanding from class XI of Senior High School. The instruments of this study consist of objective test and interview guidelines. Level of conceptual understanding categorized using CRI category. The result of this study showed that: (1) The students understand with the concept as well because of their high motivation in learning and their love with mathematics. (2) The students understand with the concept but not sure because of their lack in self-confidence, their high false fear, lack in mastering the mathematic concept, and do not careful in answering the questions. (3) The Students experiencing misconceptions that caused by a lack of understanding, and even a misunderstanding towards the concept. (4) The students do not understand/ do not know the concept caused by their haven't knowledge in answer the question of eksponent, their lack of ability and insight in working on the questions, lack of mastering the concept, not understanding the questions, and the students lack ability in transform the questions.
\end{abstract}

Keywords: Understanding, Concept, Exponent, Misconception, Certainty of Response Index (CRI). 


\section{PENDAHULUAN}

Pemahaman konsep merupakan salah satu aspek yang harus dimiliki siswa, khususnya dalam pelajaran matematika. Pemahaman konsep adalah tingkat kemampuan seseorang untuk mampu memahami suatu hal yang mendasar (konsep), yang diperolehnya dalam proses pembelajaran, sehingga tingkat pemahaman konsep dari masing-masing siswa bervariasi. Salah satu materi pada pelajaran matematika yang memerlukan pemahaman konsep yaitu perpangkatan.

Selain menjadi materi prasyarat dari logaritma, perpangkatan juga dapat membantu kita dalam menuliskan bilangan yang mungkin akan cukup panjang apabila dituliskan dalam bentuk seperti biasanya menjadi bentuk yang cukup sederhana. Contoh: 1.000 .000 .000 dapat ditulis $10^{9}$, atau angka penting yang dipelajari pada pelajaran fisika. Dengan memahami perpangkatan, akan memudahkan kita dalam memahami materi selanjutnya, khususnya logaritma.

Dalam memahami konsep, setiap siswa pasti memiliki tingkat pemahaman konsep yang berbeda-beda, khususnya pada materi perpangkatan. Ada beberapa tingkat pemahaman konsep yaitu paham konsep dengan baik, paham konsep tetapi kurang yakin, miskonsepsi, dan tidak tahu konsep. Sehingga pada proses pembelajaran setiap siswa mengalami salah satu atau beberapa tingkat pemahaman konsep tersebut. Oleh karena itu, sangat penting untuk kita mengetahui tingkat pemahaman konsep siswa pada materi perpangkatan.

Penelitian mengenai materi perpangkatan sebelumya telah dilakukan oleh Agustin \& Linguistika (2012). Pada penelitian tersebut membahas mengenai kesalahan siswa pada materi perpangkatan. Kesalahan yang diperoleh diantaranya miskonsepsi siswa pada perpangkatan yaitu $3^{2} \times 3^{2}=9^{4}$. Sementara soal tersebut dapat diselesaikan dengan menggunakan salah satu sifat perpangkatan yaitu, $a^{x} \times a^{y}=a^{x+y}$.

Salah satu metode untuk mengidentifikasi tingkat pemahaman konsep dengan menggunakan Certainty of Response Index (CRI). Metode CRI merupakan metode yang didasarkan pada tingkat keyakinan siswa atas jawaban yang diberikannya. Metode ini diperkenalkan oleh Hasan, Bagayoko, \& Kelley (1999) pada penelitian mereka yang menyatakan bahwa metode CRI efektif dalam mendiagnosis siswa yang tidak paham konsep dan siswa yang mengalami miskonsepsi. Hal tersebut dikarenakan CRI dapat mengidentifikasi keduanya berdasarkan tingkat keyakinan responden berdasarkan soal yang diberikan. CRI kemudian dimodifikasi oleh Hakim, Liliasari, \& Kadarohman (2012). Mereka memodifikasi penentuan kategori pemahaman konsep siswa berdasarkan pilihan jawaban, alasan, dan nilai CRI. Pada penelitian ini menggunakan CRI yang telah dimodifikasi oleh Hakim dkk. (2012).

Penelitian ini bertujuan untuk mengetahui bagaimana deskripsi tingkat pemahaman konsep siswa menggunakan Certainty of Response Index (CRI) kelas XI di salah satu SMA. Pada penelitian ini juga mengungkap penyebab siswa mengalami tingkat pemahaman konsep tertentu, khususnya pada materi perpangkatan.

\section{KAJIAN PUSTAKA}

\section{Pemahaman Konsep}

Pemahaman atau comprehension merupakan salah satu unsur psikologis dalam belajar yang mengharuskan siswa untuk mengerti secara mental makna dan aplikasi dari konsep sehingga siswa dapat memahami konsep secara menyeluruh (Sadirman, 2012). Menurut Anas (2009), yang dimaksud dengan pemahaman adalah kemampuan untuk menggunakan pengetahuan yang sudah diingat lebih-kurang sama dengan yang sudah diajarkan dan sesuai dengan maksud penggunaannya.

Menurut Soedjadi (2000), konsep adalah ide abstrak yang dapat digunakan untuk mengadakan klasifikasi atau penggolongan yang pada umumnya dinyatakan dengan suatu istilah atau 
rangkaian kata (lambang bahasa). Berbeda halnya dengan Bell (1978) yang menyatakan konsep dalam matematika yaitu suatu konsep dalam matematika adalah sebuah ide abstrak yang memungkinkan seseorang mengklasifikasikan objek atau peristiwa dan untuk menentukan apakah objek dan peristiwa tersebut adalah contoh atau bukan contoh dari ide abstrak.

Sehingga dapat disimpulkan bahwa, pemahaman konsep adalah proses individu menguasai informasi yang diperoleh dari pembelajaran dan pengalaman, dengan cara menerima dan memahami apa yang dipelajarinya, yang ditunjukkannya melalui cara bersikap dan berfikir dalam memahami konsep, dan kemampuan dalam memilih serta menggunakan prosedur secara efisien dan tepat.

\section{Certainty of Response Index (CRI)}

CRI pada awalnya merupakan metode untuk mengukur suatu miskonsepsi yang tengah terjadi. Dengan metode CRI, responden diminta untuk memberikan tingkat keyakinan dari kemampuan mereka sendiri, dengan mengasosiasikan tingkat keyakinan tersebut dengan pengetahuan, konsep, atau hukum (Hasan dkk., 1999).

CRI yang ditemukan oleh Hasan dkk. (1999), hanya mengungkap tiga kategori pemahaman konsep, dan hanya menggunakan tes pilihan ganda yang disertai skala CRI. Sedangkan CRI yang dikembangkan oleh Hakim dkk. (2012) membagi pemahaman konsep menjadi empat kategori pemahaman konsep, dengan menggunakan tes pilihan ganda beralasan yang disertai skala CRI.

Metode CRI pada penelitian ini meminta responden untuk menjawab pertanyaan, menuliskan alasan terhadap jawabannya, dan disertai dengan pemberian derajat atau skala keyakinan responden dalam menjawab pertanyaan yang diberikan. Sehingga metode ini dapat menggambarkan keyakinan siswa terhadap kebenaran dari jawaban dan alasan yang diresponnya. Setiap pilihan respon memiliki nilai skala (Hasan dkk., 1999).

TABEL 1. Skala (tingkat) keyakinan responden dalam menjawab pertanyaan

\begin{tabular}{cc}
\hline CRI & Kriteria \\
\hline 5 & Pasti Benar \\
4 & Benar \\
3 & Yakin \\
2 & Tidak Yakin \\
1 & Menebak \\
0 & Asal Menebak \\
\hline
\end{tabular}

Tabel 1 tercermin tingkat keyakinan jawaban dalam skala CRI yang diberikan. CRI yang rendah menandakan ketidakyakinan konsep siswa dalam menjawab pertanyaan, sedangkan CRI yang tinggi menandakan keyakinan konsep siswa dalam menjawab pertanyaan. Kelemahan tes pilihan ganda dengan metode CRI terletak dalam pengkategorian peserta didik yang memiliki tingkat kepercayaan diri yang rendah berdasarkan skala CRI dan besarnya faktor menebak siswa dalam menjawab soal. Hal ini ditandai dengan adanya siswa yang sebenarnya mampu menjawab dan memahami konsep-konsep yang terdapat pada soal, namun karena memiliki tingkat keyakinan yang rendah menuntunnya memilih CRI yang rendah, sehingga dikelompokkan dalam kategori tidak paham konsep.

Dengan memperhatikan kondisi ini, maka kategori pemahaman yang disusun oleh Hasan dkk. (1999) dimodifikasi oleh Hakim dkk. (2012) dengan menambahkan alasan terbuka pada tes pilihan ganda. Sehingga siswa memahami konsep dengan baik tetapi memiliki CRI yang rendah masuk ke dalam kategori paham konsep tetapi kurang yakin. Jadi, penentuan kategori tingkat pemahaman konsep siswa berdasarkan pada pilihan jawaban, alasan, dan nilai CRI. Kategori tingkat pemahaman ini berdasarkan pengkategorian tingkat pemahaman konsep (Hakim dkk., 2012). 
TABEL 2. Kategori Pemahaman Konsep pada CRI

\begin{tabular}{llcl}
\hline Jawaban & Alasan & Nilai CRI & \multicolumn{1}{c}{ Deskripsi } \\
\hline Benar & Benar & $>2,5$ & Memahami Konsep dengan Baik \\
Benar & Benar & $<2,5$ & Memahami Konsep Tetapi Kurang Yakin \\
Benar & Salah & $>2,5$ & Miskonsepsi \\
Benar & Salah & $<2,5$ & Tidak Tahu Konsep \\
Salah & Benar & $>2,5$ & Miskonsepsi \\
Salah & Benar & $<2,5$ & Tidak Tahu Konsep \\
Salah & Salah & $>2,5$ & Miskonsepsi \\
Salah & Salah & $<2,5$ & Tidak Tahu Konsep \\
\hline
\end{tabular}

Tabel 2 digunakan untuk melakukan pengkategorian yang diperoleh dari kombinasi antara jawaban, alasan, dan nilai CRI siswa pada tes objektif yang dilakukan, serta untuk membedakan tingkat pemahaman konsep dari masing-masing siswa, yaitu antara siswa yang paham konsep dengan baik, paham konsep tetapi kurang yakin, miskonsepsi, atau siswa yang tidak tahu konsep.

\section{METODE PENELITIAN}

Penelitian ini merupakan penelitian kualitatif dengan pendekatan deskriptif, penelitian dilaksanakan di kelas XI pada salah satu SMA. Subjek dalam penelitian ini terdiri dari 11 subjek, yaitu 3 subjek yang paham konsep dengan baik (PKB), 3 subjek yang paham konsep tetapi kurang yakin (PKY), 6 subjek yang mengalami miskonsepsi (M), dan 3 subjek yang tidak tahu konsep (TTK), dalam hal ini terdapat subjek yang mengalami beberapa tingkat pemahamn konsep yang berbeda pada soal yang berbeda. Instrumen yang digunakan yaitu tes objektif berbentuk tes pilihan ganda beralasan (proses penyelesaian) yang disertai dengan skala $C R I$, dan pedoman wawancara yang telah divalidasi oleh dua orang ahli. Teknik pengumpulan data dalam penelitian ini, yaitu tes objektif yang digunakan untuk mengetahui tingkat pemahaman konsep perpangkatan siswa, kemudian wawancara digunakan untuk menggali data-data tingkat pemahaman konsep perpangkatan siswa guna memperjelas data hasil tes objektif, yang tidak semuanya dapat dijelaskan melalui analisa hasil jawaban tes objektif siswa, dan dokumentasi digunakan untuk melengkapi data-data dari wawancara, serta catatan lapangan yaitu foto-foto serta rekaman suara.

Pengambilan data dalam penelitian ini dimulai dengan melakukan tes objektif kepada seluruh siswa kelas XI, kemudian menganalisis jawaban setiap siswa, lalu mengelompokkan siswa kedalam empat tingkat pemahaman konsep sesuai dengan pengkategorian CRI. Langkah selanjutnya adalah memilih beberapa siswa yang akan menjadi subjek penelitian yang dapat memenuhi setiap tingkat pemahaman konsep pada setiap soal yang memungkinkan, dalam penelitian ini sebanyak 11 subjek. Kemudian, untuk memperjelas data hasil tes objektif, maka dilanjutkan dengan wawancara terhadap subjek. Data dari hasil wawancara tersebut kemudian dideskripsikan. Deskripsi dari wawancara tersebut akan menggambarkan tingkat pemahaman konsep siswa serta penyebab. Yang terakhir adalah penyajian data, data hasil tes dan wawancara tersebut disajikan dalam bentuk uraian.

\section{HASIL DAN PEMBAHASAN}

Pada bagian ini dipaparkan data hasil penelitian, yaitu Deskripsi tingkat pemahaman konsep siswa pada materi perpangkatan menggunakan Certainty of Response Index (CRI), serta penyebab tingkat pemahaman konsep tertentu. 


\section{Paham Konsep dengan Baik}

Berikut ini disajikan hasil tes dan petikan wawancara subjek PBK pada soal nomor 1 dan nomor 6. Selanjutnya dideskripsikan secara singkat mengenai tingkat pemahaman konsep perpangkatan siswa dalam penyelesaian masalah secara lisan dan tulisan.

$$
\begin{aligned}
& \text { Perhatikan bentuk perkalian berulang berikut ini } \\
& t \times a \times t \times a \times t \times a \\
& \begin{array}{ll}
\text { i. } t^{3}+a^{3} & \text { iii. }(t \times a)^{3} \\
\text { ii. }(t+a)^{3} & \text { iv. } t^{3} \times a^{3}
\end{array} \\
& \text { Yang manakah bentuk perpangkatan yang benar dari } \\
& \text { bentuk perkalian diatas ... } \\
& \begin{array}{ll}
\text { a. i dan ii } & \text { c. iii dan iv } \\
\text { b. ii dan iii } & \text { d. i dan iv }
\end{array}
\end{aligned}
$$
a. i dan ii
c. iii dan iv
b. ii dan iii
d. i dan iv

(a)

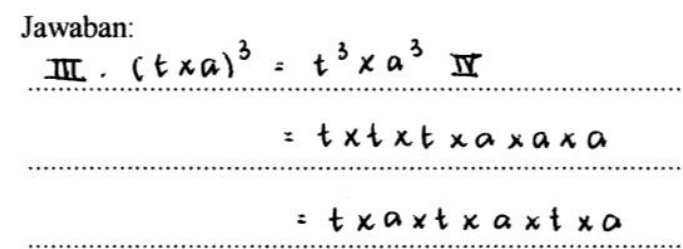

(b)

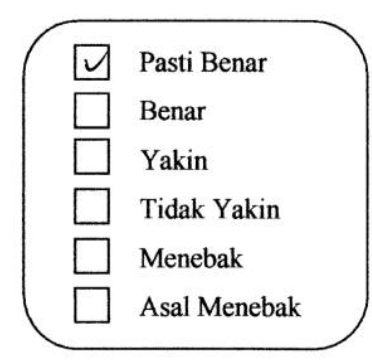

(c)

GAMBAR 1. Jawaban, Alasan, dan CRI Subjek PBK nomor 1

Pada Gambar 1(a) terlihat subjek PKB menjawab soal dengan benar, yaitu memilih c. Gambar 1(b) terlihat subjek PKB memberi alasan dengan proses penyelesaian yang benar, yaitu subjek PKB terlebih dahulu menyamakan iii dan iv, kemudian menjabarkan iv kemudian menghasilkan penjabaran iii dengan menggunakan sifat komtatif pada perkalian. Gambar 1(c) terlihat subjek PKB mencentang pasti benar pada skala CRI yang disediakan. Dengan merujuk pada pengkategorian tingkat pemaham konsep CRI pada Tabel 2, maka subjek PKB termasuk pada tingkat paham konsep dengan baik.

Untuk mengetahui apakah subjek PKB benar-benar paham konsep dengan baik, maka dilakukan wawancara pada subjek PKB. Wawancara dimulai dengan meminta subjek untuk memperhatikan kembali jawabannya, setelah itu meminta subjek PKB untuk menjelaskan jawabannya. Hal ini diperkuat pada cuplikan penjelasan subjek PKB pada Transkrip 1:

\section{TRANSKRIP 1}

$\mathrm{S}_{\mathrm{PKB}, 1,2} \quad$ Kan di sini kak tiga t nya baru kali semua, a nya juga tiga. Biasanya kalau kali semua itu kak, berpangkat. Kan tiga t nya, berarti pangkat tiga, a nya juga tiga, a nya juga pangkat tiga. Karna itu kak iii dan iv kupilih. Karena misalnya $i$ dan ii kupilih kak, tambah i bukan tu kali.

$\mathrm{P}_{4} \quad$ Yakinki?

$\mathrm{S}_{\mathrm{PKB}, 1,4} \quad$ Iye kak

$\mathrm{P}_{7} \quad$ Kita suka belajar matematika memang dek?

$\mathrm{S}_{\mathrm{PKB}, 2,7} \quad$ Iye kak 
Pada Transkrip 1, subjek PKB menjelaskan bahwa terdapat tiga $t$ dengan operasi perkalian, sehingga menghasilkan $t^{3}$, begitupula dengan $a$. Kemudian subjek PKB menjelaskan mengapa tidak memilih i dan ii, karena i dan ii menggunakan operasi penjumlahan. Terlihat pula pada Transkrip 1, ternyata subjek PKB menyukai matematika.

Hal tersebut sejalan dengan pandangan Siregar (2017) yaitu jika persepsi siswa mengenai pelajaran matematika mudah maka siswa tersebut sangat menyukai matematika dan menjadikan matematika sebagai pelajaran favoritnya, begitupun sebaliknya.

Dari hasil tes pada Gambar 1 dan hasil wawancara pada Transkrip 1, subjek PKB benar memahami konsep dengan baik. Selain jawaban pada tes yang memperlihatkan bahwa subjek PKB termasuk pada kategori paham konsep dengan baik, penjelasan pada Transkrip 1 pun menguatkan bahwa subjek PKB paham konsep dengan baik.

\section{Paham Konsep tetapi Kurang Yakin}

Berikut ini disajikan hasil tes dan petikan wawancara subjek PBK pada soal nomor 2. Selanjutnya dideskripsikan secara singkat mengenai tingkat paham konsep perpangkatan tetapikurang yakin dalam penyelesaian masalah secara lisan dan tulisan.

Dinomor berapakah kesalahan dimulai dalam menyederhanakan hasil perkalian dari

$$
\underbrace{3^{6} \times 3^{4}}_{1}=(\underbrace{3 \times 3)^{6+4}}_{2}=\underbrace{9^{10}}_{3}=\underbrace{3^{20}}_{4}
$$
a. 1
c. 3
b. 2
d. 4

(a)

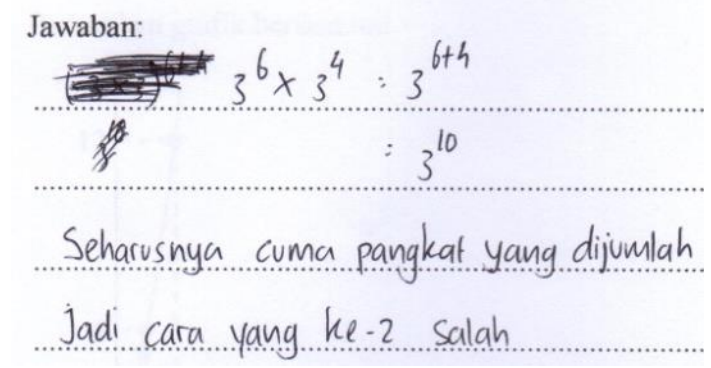

(b)

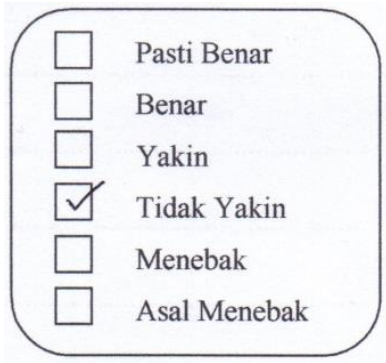

(c)

GAMBAR 2. Jawaban, Alasan, dan Nilai CRI Subjek PKY nomor 2

Pada Gambar 2(a) terlihat subjek PKY menjawab soal dengan benar, yaitu memilih b. Gambar 2(b) terlihat subjek PKY memberi alasan dengan proses penyelesaian yang benar, yaitu subjek PKY menggunakan sifat perpangkatan yaitu, jika terdapat basis yang sama dengan operasi perkalian, maka cukup menuliskan satu saja basis tersebut, lalu pangkat dari masing-masing basis tersebut dijumlahkan, tanpa memproses basis tersebut. Gambar 2(c) terlihat subjek PKY mencentang tidak yakin pada skala CRI yang disediakan. Dengan merujuk pada pengkategorian tingkat pemaham konsep CRI pada Tabel 2, maka subjek PKY termasuk pada tingkat paham konsep tetapi kurang yakin.

Untuk mengetahui penyebab siswa kurang yakin dengan jawabannya maka dilakukan wawancara kepada subjek PKY. Dari hasil wawancara diketahui bahwa subjek PKY memilih 
tidak yakin karna subjek PKY tidak percaya diri dengan jawabannya. Hal ini diperkuat pada cuplikan wawancara subjek PKY pada Transkrip 2:

\title{
TRANSKRIP 2
}

\author{
$\mathrm{P}_{2} \quad$ Tidak yakinki di sini dek? \\ $\mathrm{S}_{\mathrm{PKY}, 2,2} \quad$ Iye $k a k$ \\ $\mathrm{P}_{3} \quad$ Apa alasanta kenapa kurang yakinki dengan jawabanta? \\ $\mathrm{S}_{\mathrm{PKY}, 2,3} \quad$ Karena waktu tes tidak bisaki bertanya sama teman kak, dan memang tidak \\ pintarka matematika, jadi tidak yakinka kak
}

Pada Transkrip 2, subjek PKY memilih tidak yakin meskipun jawaban dan alasan yang dituliskannya sudah benar, karena subjek PKY tidak dapat bertanya kepada teman yang lebih pintar matematika menurut subjek PKY. subjek PKY merasa tidak pintar pada mata pelajaran matematika, dan harus memastikan jawaban yang dirinya peroleh ke temannya.

Hal ini diperkuat oleh Sari (2009) mengemukakan penyebab-penyebab rasa kurang percaya diri siswa dalam pembelajaran, salah satunya adalah bahwa karakter siswa umumnya mempunyai rasa takut yaitu takut salah. Termasuk dalam hal ini adalah takut jawabannya salah ketika menjawab soal.

Dari hasil tes pada Gambar 2 dan hasil wawancara pada Transkrip 2, subjek PKY benar memahami konsep tetapi kurang yakin. Selain jawaban pada tes yang memperlihatkan bahwa subjek PKY termasuk pada kategori paham konsep tetapi kurang yakin, dan penjelasan pada Transkrip 2 pun menguatkan bahwa subjek PKY paham konsep tetapi kurang yakin.

\section{Miskonsepsi}

Berikut ini disajikan hasil tes dan petikan wawancara subjek M pada soal nomor 7. Selanjutnya dideskripsikan secara singkat mengenai subjek yang mengalami miskonsepsi dalam penyelesaian masalah secara lisan dan tulisan.

$$
\begin{aligned}
& \text { Jika } 2^{(2 x-1)}-4=2^{x}, \text { maka } x=\cdots \\
& \text { a. }-2 \\
& \text { b. } 2 \\
& \text { c. } 3 \\
& \text { d. } 4
\end{aligned}
$$

(a)

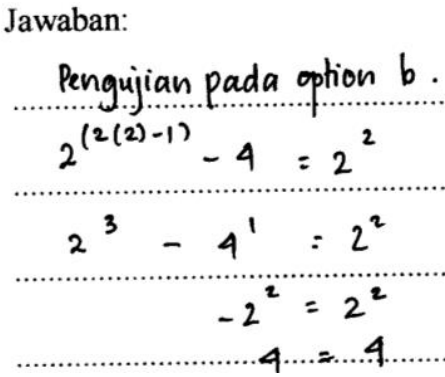

(b)

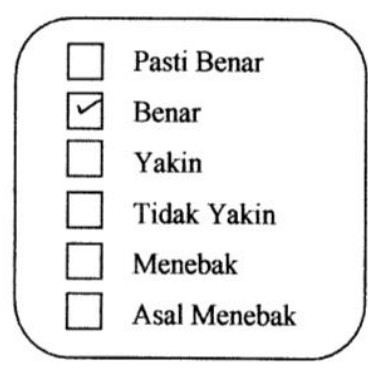

(c)

GAMBAR 3. Jawaban, Alasan, dan Nilai CRI Subjek M nomor 7

Pada Gambar 3(a) terlihat subjek M menjawab soal kurang tepat, yaitu memilih d, seharusnya b. Gambar 3(b) terlihat subjek M memberi alasan dengan proses penyelesaian yang salah, yaitu 
subjek M mengalami miskonsepsi pada operasi pengurangan perpangkatan, subjek M langsung mengurangkan bilangan pokok dengan bilangan pokok, dan mengurangkan pangkat dengan pangkat, dan subjek $M$ mengira bahwa $-2^{2}=2^{2}$. Gambar 3(c) terlihat subjek $M$ mencentang benar pada skala CRI yang disediakan. Dengan merujuk pada pengkategorian tingkat pemaham konsep CRI pada Tabel 2, maka subjek M termasuk pada tingkat miskonsepsi.

Untuk mengetahui penyebab mengalami miskonsepsi, maka dilakukan wawancara kepada subjek M. Dari hasil wawancara diketahui bahwa subjek M mencentang benar, karna subjek $M$ pada awalnya tidak mengetahui bahwa hal yang dilakukannya salah. Hal ini diperkuat pada cuplikan wawancara subjek M pada Transkrip 3:

\section{TRANSKRIP 3}

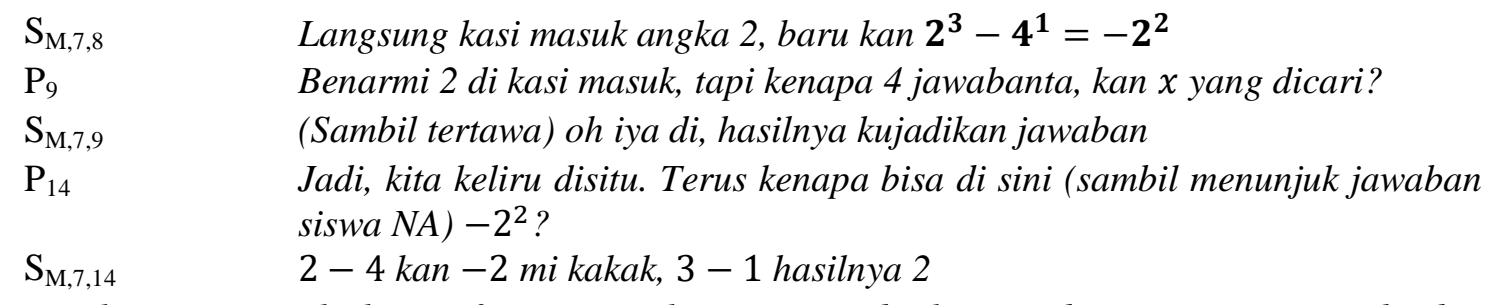

Penilitipun menjelaskan sifat perpangkatan yang berkaitan dengan nomor tujuh dan menjelaskan letak kesalahan yang dilakukan oleh subjek $M$, dan pada saat dijelaskan subjek $M$ mulai bingung kembali

$\mathrm{P}_{16} \quad$ Tidak boleh 2-4 baru 3-1 nah

$\mathrm{S}_{\mathrm{M}, 7,16 \quad \text { Kenapa kak? }}$

Penelitipun memberikan contoh kepada subjek $M$, agar subjek $M$ tidak melakukan kesalahan tersebut lagi. Dan subjek $M$ pun paham setelah diberikan contoh. Penelitipun memberi tahu kepada subjek $M$ bahwa $-\mathbf{2}^{\mathbf{2}} \neq \mathbf{2}^{\mathbf{2}}$.

Pada Transkrip 3, subjek $M$ terlebih dahulu mensubtitusi $x=2$, sehingga menghasilkan $2^{3}-4^{1}=-2^{2}$. Kemudian subjek $M$ menyadari jawaban yang dipilihnya kurang tepat, yaitu menjadikan hasil akhir sebagai jawaban benar, seharusnya memilih 2 yang merupakan nilai dari $x$. Diketahui pulabahwa subjek $M$ mengalami miskonsepsi pada proses pengerjaannya, yaitu $2^{3}-4^{1}=-2^{2}$. Menurut subjek $\mathrm{M}-2^{2}$ diperoleh dari bilangan pokok saling dikurangkan yaitu $2-4=-2$ dan pangkat pun saling dikurangkan yaitu $3-1=2$, sehingga -2 sebagai bilangan pokok dan 2 sebagai pangkat. Selain itu, subjek M miskonsepsi pada sifat dasar operasi bilangan bulat yang mengira $-2^{2}=2^{2}$.

Subjek M mengira jawaban akhir sebagai jawaban yang benar tanpa memahami apa yang ditanyakan pada soal, dan yakin dengan penyelesaiannya yang kurang tepat yaitu $2^{3}-4^{1}=$ $-2^{2}$. Miskonsepsi ini disebabkan karena subjek M memiliki konsep yang salah dan yakin akan jawabannya, hal tersebut diperkuat oleh Sadhu dkk. (2017) bahwa miskonsepsi pada siswa disebabkan karena siswa yang memiliki konsep yang salah ketika menjawab pertanyaan cenderung merasa yakin atau percaya diri dengan jawaban mereka, hal inilah disebut miskonsepsi. Miskonsepsi lainnya sesuai dengan yang disinyalir oleh Allen (2007) bahwa pada perpangkatan, salah satu miskonsepsi yang dilakukan siswa adalah siswa memiliki masalah pada urutan operasi, yaitu mengira $-4^{2}=16$ seharusnya $(-4)^{2}=16$.

Dari hasil tes pada Gambar 3 dan hasil wawancara pada Transkrip 3, subjek M benar mengalami miskonsepsi. Selain jawaban pada tes yang memperlihatkan bahwa subjek M termasuk pada kategori miskonsepsi, dan penjelasan pada Transkrip 3 pun menguatkan bahwa subjek $\mathrm{M}$ miskonsepsi. Perlu diingat bahwa jika kesalahpahaman tidak diperbaiki, konsep baru akan sulit dipelajari (Gonen, S., \& Kocakaya, S., 2010). 


\section{Tidak Tahu Konsep}

Berikut ini disajikan hasil tes dan petikan wawancara subjek TTK pada soal nomor 9. Selanjutnya dideskripsikan secara singkat mengenai subjek pada tingkat tidak tahu konsep dalam penyelesaian masalah secara lisan dan tulisan.

Dalam sebuah penelitian, diketahui seekor amoeba $\mathrm{T}$ berkembang biak dengan membelah diri sebanyak 2 kali setiap 30 menit. Berapa banyak amoeba T selama satu hari jika dalam suatu pengamatan terdapat 4 ekor amoeba T?
b. $2^{49}$
c. $2^{96}$
d. $2^{98}$

(a)

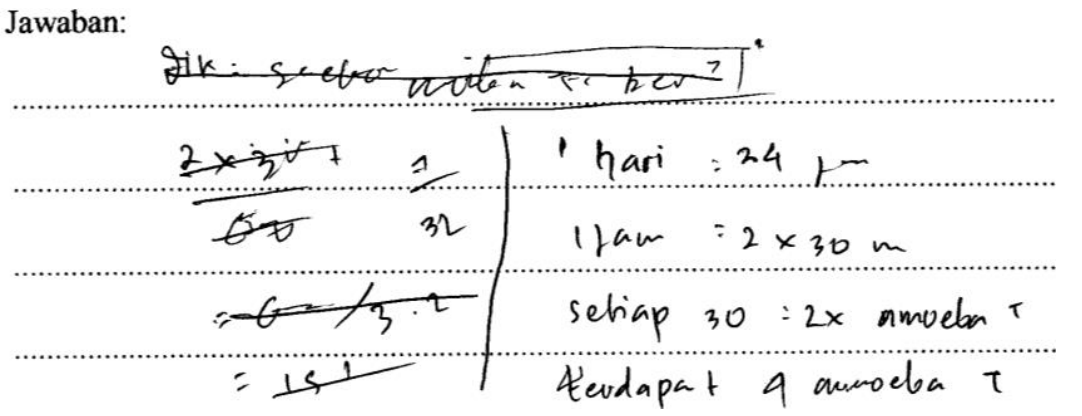

(b)

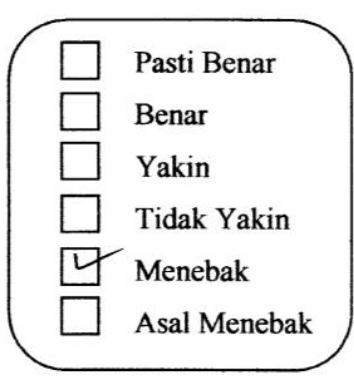

(c)

GAMBAR 4. Jawaban, Alasan, dan Nilai CRI Subjek TTK soal nomor 9

Pada Gambar 4(a) terlihat subjek TTK menjawab soal kurang tepat, yaitu memilih a, seharusnya d. Gambar 4(b) terlihat subjek TTK memberi alasan dengan proses penyelesaian yang belum tepat, yaitu subjek TTK hanya menuliskan yang diketahui dari soal. Gambar 4(c) terlihat subjek TTK mencentang menebak pada skala CRI yang disediakan. Dengan merujuk pada pengkategorian tingkat pemaham konsep CRI pada Tabel 2., maka subjek M termasuk pada tingkat tidak tahu konsep.

Untuk mengetahui apakah subjek TTK benar-benar tidak paham konsep, maka peneliti melakukan wawancara kepada subjek TTK. Dari jawaban dan hasil wawancara, yang menyebabkan subjek TTK hanya menuliskan hal yang diketahui saja, karena subjek TTK diketahui kurang memiliki kemampuan dan wawasan dalam mengerjakan soal, yaitu subjek tidak tahu mentransformasikan soal kedalam bentuk matematika. Hal ini diperkuat pada cuplikan wawancara subjek TTK pada Transkrip 4:

\section{TRANSKRIP 4}

$\begin{array}{ll}\mathrm{P}_{56} & \text { Bisa kita jelaskanka jawabanta? } \\ \mathrm{S}_{\mathrm{TTK}, 9,56} & \text { (Tidak ada jawaban) } \\ \mathrm{P}_{57} & \text { Tidak kita tahu mau diapakan ini soal dek? } \\ \mathrm{S}_{\mathrm{TTK}, 9,57} & \text { Iye kak }\end{array}$

Pada Transkrip 4, subjek TTK tidak dapat menjelaskan jawaban yang dituliskannya, tidak mengerti maksud dari soal, dan tidak tahu mengerjakan soal tersebut. Hal ini diperkuat oleh 
Khasanah (2015) yang mengemukakan faktor siswa kesulitan dalam mengerjakan soal pemecahan masalah yaitu siswa tidak mampu mengidentifikasi dengan baik maksud soal, Siswa tidak dapat mengidentifikasi/menuliskan apa yang ditanyakan dan dicari, dan kurangnya kemampuan siswa dalam mentransformasikan kalimat kedalam model matematika.

Dari hasil tes pada Gambar 4 dan hasil wawancara pada Transkrip 4, subjek TTK ini benar tidak memahami konsep, selain jawaban pada lembar tes, penjelasan pada Transkrip 4 juga menggambarkan bahwa subjek TTK sama sekali tidak dapat menyelesaikan soal nomor 9 .

\section{KESIMPULAN}

Berdasarkan hasil dan pembahasan, maka dapat disimpulkan beberapa hal yaitu:

1. Siswa dengan tingkat paham konsep perpangkatan yang baik/tinggi, menjawab dan memberi alasan yang tepat, serta mempunyai tingkat keyakinan jawaban, yaitu pasti benar, benar dan atau yakin. Siswa memahami konsep dengan baik, disebabkan karena tingginya motivasi belajar dan rasa suka siswa terhadap pelajaran matematika.

2. Siswa dengan tingkat paham konsep perpangkatan tetapi kurang yakin, menjawab dan memberi alasan dengan benar, tetapi memilih tidak yakin pada tingkat keyakinan jawaban. Siswa kurang yakin dengan pemahaman mereka sendiri, walaupun pemahamannya sudah benar, disebabkan karena kurangnya rasa percaya diri siswa, rasa takut salah yang tinggi, kurang menguasai konsep matematika khususnya perpangkatan, dan tergesa-gesa dalam menjawab soal.

3. Siswa yang mengalami miskonsepsi pada perpangkatan, menjawab dengan benar, tetapi memberi alasan yang salah, dan mempunyai tingkat keyakinan pasti benar, benar, dan atau yakin. Hal ini disebabkan karena siswa kurang memahami bahkan salah memahami konsep dasar perpangkatan, khususnya pada sifat-sifat perpangkatan. Beberapa jenis miskonsepsi pada penelitian ini yaitu, miskonsepsi pada notasi, miskonsepsi pada urutan operasi, miskonsepsi akibat kesalahan sistematika, dan miskonsepsi akibat kesalahan transformasi.

4. Siswa dengan tingkat tidak tahu/ kurang memahami konsep perpangkatan, menjawab dan memberi alasan yang salah, serta mempunyai tingkat keyakinan yaitu tidak yakin, menebak atau asal menebak. Siswa tidak tahu konsep disebabkan karena kurangnya kemampuan dan wawasan siswa dalam mengerjakan soal, kurang menguasai konsep perpangkatan, tidak mampu mengidentifikasi dengan baik maksud dari soal, kurangnya kemampuan siswa dalam mentransformasikan soal kedalam model matematika, dan kurangnya penguasaan konsep yang diterapkan, sehingga siswa sulit menentukan rumus atau strategi yang digunakan.

\section{DAFTAR PUSTAKA}

Agustin, K., \& Linguistika, Y. (2012). Identifikasi Kesalahan Siswa Kelas X Pada Evaluasi Materi Sifat-Sifat Bilangan Berpangkat dengan Pangkat Bilangan Bulat Di SMA Muhammadiyah 2 Yogyakarta. Prosiding Seminar Nasional Matematika dan Pendidikan Matematika FMIPA UNY. Yogyakarta: Jurusan Pendidikan Matematika FMIPA UNY.

Allen, S., \& Kerry, D. (2007). The Effects of Father Involvement: An Updated Research Summary of the Evidence Inventory. Guelph: Father Involvement Research Alliance

Anas, Y. (2009). Managemen Pembelajaran dan Instruksi Pendidikan. Jogja: IRCiSoD.

Bell, F.H. (1978). Teaching and Learning Mathematics (In Secondary Schools). United States of America: Wm. C. Brown Company Publishers. 
Gonen, S, and Kocakaya, S. 2010, A Physics Lesson Designed According to 7E Model with the Help of Instructional Technology (Lesson Plan). Turkish Online Journal of Distance Education, 11(1). 98-113.

Hakim, A., Liliasari, \& Kadarohman, A. (2012). Student Concept Understanding of Natural Products Chemistry in Primary and Secondary Metabolites Using the Data Collecting Technique of Modified CRI. International Online Journal of Educational Sciences, 2012, 4 (3), 544-553.

Hasan, S., D. Bagayoko, D., \& Kelley, E. L. (1999). Misconseptions and the Certainty of Response Index (CRI). Phys. Educ. 34(5), pp. 294 - 299.

Khasanah, U. (2015). Kesulitan Menyelesaikan Soal Cerita Matematika Pada Siswa Smp Negeri 1 Colomadu Tahun Pelajaran 2014/2015 (Doctoral dissertation). Universitas Muhammadiyah Surakarta, Surakarta.

Sadhu, S., dkk. (2017). Analysis of acid-base misconceptions using modified certainty of response index (CRI) and diagnostic interview for different student levels cognitive. International Journal of Science and Applied Science: Conference Series, 2017, 1(2), 91-100.

Sadirman, A.M. (2012). Interaksi dan Motivasi Belajar Mengajar. Raja Grafindo Persada: Jakarta.

Sari, I., M. (2009). Usaha Peningkatan Kepercayaan Diri Siswa Mengerjakan Soal Matematika Melalui Pembelajaran dengan Pendekatan Interaktif (Skripsi, dipublikasikan). Surakarta: Universitas Muhammadiyah Surakarta.

Siregar, N., R. (2017). Persepsi Siswa Pada Pelajaran Matematika: Studi Pendahuluan Pada Siswa yang Menyenangi Game. Prosiding Temu Ilmiah X Ikatan Psikologi Perkembangan Indonesia.Semarang.

Soedjadi, R. (2000). Kiat Pendidikan Matematika di Indonesia: Konstatasi Keadaan Masa Kini Menuju Harapan Masa Depan. Jakarta: Direktorat Jenderal Pendidikan Tinggi, Departemen Pendidikan Nasional. 